\title{
Increased spontaneous release of tumour necrosis factor- $\alpha$ by alveolar macrophages from wheezy infants
}

\author{
I. Azevedo*, J. de Blic**, C.H. Dumarey*, P. Scheinmann**, \\ B.B. Vargaftig*, M. Bachelet*
}

Increased spontaneous release of tumour necrosis factor- $\alpha$ by alveolar macrophages from wheezy infants. I. Azevedo, J. de Blic, C.H. Dumarey, P. Scheinmann, B.B. Vargaftig, M. Bachelet. @ERS Journals Ltd 1997.

ABSTRACT: We determined if alveolar macrophages (AMs) from infants with severe recurrent wheezing episodes release increased amounts of tumour necrosis factor- $\alpha$ (TNF- $\alpha)$, as described in adults with asthma.

We compared TNF- $\alpha$ release by unstimulated and lipopolysaccharide-stimulated AMs obtained by bronchoalveolar lavage in 13 wheezy and seven nonwheezy infants (aged 6-36 months) and analysed its regulation by dexamethasone. Metabolites in cell supernatants were quantified by enzyme-linked immunosorbent assay (ELISA) $\left(\mathrm{TNF}-\alpha\right.$ ) or radioimmunoassay (thromboxane $\mathbf{B}_{2}$ and prostaglandin $\mathbf{E}_{2}$ ). Comparison of results was performed by the Mann-Whitney U-test and values were expressed as median (interquartile range) in $\mathbf{n g} \cdot \mathbf{1 0}^{6}$ cells $^{-1}$.

Resting AMs from wheezy infants released larger amounts of TNF- $\alpha$ and thromboxane $B_{2}$ as compared to controls: $2.67(0.89-8.33)$ vs $0.48(0.25-1.08)$ and 75.63 (38.07-158.91) vs 10.03 (7.36-76.08), respectively $(\mathbf{p}<0.05)$. When stimulated overnight with bacterial lipopolysaccharide, AMs from both groups released similar amounts of metabolites. Dexamethasone induced a consistent inhibition of the lipopolysaccharide-stimulated release of all the mediators.

Our results show that alveolar macrophages from wheezy infants are activated to release increased amounts of tumour necrosis factor- $\alpha$, as in asthma, and suggest that infants with recurrent wheezing may eventually benefit from treatment with glucocorticoids.

Eur Respir J 1997; 10: 1767-1773.
*Unité de Pharmacologie Cellulaire, Unité Associée Institut Pasteur-INSERM U-285 and **Service de Pneumologie et d'Allergologie Pédiatriques, Hôpital Necker-Enfants Malades, Paris, France.

Correspondence: M. Bachelet Laboratoire de Physiologie Respiratoire UFR Cochin-Port Royal

24 rue du Faubourg St Jacques 75014 Paris

France

Keywords: Alveolar macrophage asthma

bronchoalveolar lavage

infants

tumour necrosis factor- $\alpha$ wheezing

I. Azevedo was supported by Grant BD/2133/92-1D from Programa Ciência, JNICT, Portugal.

Received: October 211996

Accepted after revision April 221997
Episodes of wheezing are very common in infancy but, in spite of their high incidence, the relationship between these episodes and evolution to asthma is not clearly established. While the majority of wheezy infants will not have further wheezing episodes after 3 yrs of age, some will continue to wheeze, suggesting that early wheezing is a manifestation of a predisposition to asthma in a minority of children [1]. In those in whom wheezing persists, lung function is normal in the first year of life, but reduced at age $6 \mathrm{yrs}$; one hypothesis for this deterioration in lung function is the presence of a chronic disease process of the bronchi in the subset of early wheezers, much as in older asthmatic subjects [1]. Nevertheless, the presence of inflammation within the airways of these wheezy children remains to be clearly demonstrated.

Inflammation is present within the airways of virtually all asthmatic adults [2], and involves an array of cells and mediators. Alveolar macrophages (AMs) are probably implicated in this process, since AMs from asthmatic subjects are activated to produce a wide range of inflammatory mediators with potent bronchoconstrictor and chemoattractant actions [3]. Evidence for an increased release of eicosanoids by AMs in adults with asthma is provided by the studies of CHANEZ et al.
[4] and DAMON et al. [5]. In a previous study, we showed that AMs from wheezy infants also spontaneously release increased amounts of eicosanoids, when compared to control children [6].

Tumour necrosis factor- $\alpha$ (TNF- $\alpha$ ), a major product of the activated AM [7], displays a number of actions in vitro that may contribute to the inflammation of the asthmatic airways. TNF- $\alpha$ can up-regulate the expression of adhesion molecules on endothelial cells [8], is a chemoattractant for neutrophils and monocytes [9], activates a variety of cell types $[10,11]$, and stimulates fibroblast proliferation [12]. In vivo, recombinant human $\mathrm{TNF}-\alpha$ induces an increased airway responsiveness in normal subjects and is associated with an increase in the number of neutrophils in sputum [13]. Levels of TNF- $\alpha$ in bronchoalveolar lavage (BAL) fluid are increased in symptomatic asthmatic adults, when compared to asymptomatic patients [14], and after segmental allergen provocation, in atopic asthmatics [15]. In asthmatics there is also an increase in the number of BAL cells expressing TNF- $\alpha$ messenger ribonucleic acid (mRNA) [16] and a higher secretion of TNF- $\alpha$ by BAL leucocytes [17]. Finally, AMs from adults with asthma release increased amounts of TNF- $\alpha$, both spontaneously $[18,19]$ and following bronchial allergen challenge in 
patients exhibiting a late asthmatic reaction [20]. Taken together, these studies support the hypothesis that TNF$\alpha$ is a pivotal cytokine in the pathogenesis of inflammation of the asthmatic airways.

In infants, BALFOUR-LYNN et al. [21] have detected increased levels of TNF- $\alpha$ in nasal lining fluid during acute episodes of wheezing, as compared to the corresponding levels after recovery, suggesting that TNF- $\alpha$ is also involved in acute wheezing of infants. However, to our knowledge, no data are available concerning increased TNF- $\alpha$ release in infants with recurrent episodes of wheezing.

In the present study, we examined whether TNF- $\alpha$ is released in increased amounts by AMs from infants with recurrent episodes of wheezing, during periods free of acute episodes. The release of eicosanoids by AMs from infants was followed in parallel. Moreover, since glucocorticoids seem to have a role in the prevention of early wheezing episodes [22, 23], we also determined whether dexamethasone might down-regulate the release of these proinflammatory mediators by AMs from infants.

\section{Materials and methods}

\section{Population}

The protocol for these studies was approved by the hospital Ethics Committee and informed consent was obtained from the parents of the children. Subjects were 20 children, aged 6-36 months, divided into two groups: wheezers and nonwheezers.

Thirteen children (eight males and five females; mean ( \pm SEM) age $10.6 \pm 1.0$ months) had experienced three or more moderate-to-severe episodes of wheezing. Severity and/or frequency of symptoms (more than once a month) and poor response to bronchodilators dictated the realization of flexible bronchoscopy (FB) in search of airways abnormalities. A family history of atopyrelated diseases (allergic rhinitis, asthma, or eczema) was present in five cases, absent in six, and unclear in two who were, therefore, not included in the atopyrelated analysis. Three of the five children with an atopic background also had current or past atopic dermatitis, associated in one case with increased serum immunoglobulin E (IgE) levels. Bronchoscopy was performed in a symptom-free period, and none of the children had been treated with glucocorticoids or with $\beta$-adrenergic agonists for 2 weeks prior to the study. At the time of FB, none of the children presented signs of respiratory distress; transcutaneous oxygen saturation before examination was $>95 \%$.

Because it was ethically unacceptable to have normal children as control subjects, we chose for comparison a population of seven children (five males and two females; mean age $22.9 \pm 1.6$ months), without past or present wheezing, who had undergone FB for investigation of active pulmonary tuberculosis $(n=4)$, suspicion of foreign body aspiration $(n=2)$, or persistent pulmonary infiltrate $(n=1)$. None of the wheezy or control children had cystic fibrosis, congenital or acquired immune deficiencies or congenital malformations.

\section{Study design}

We compared the in vitro TNF- $\alpha$, thromboxane $\mathrm{B}_{2}$ $\left(\mathrm{TxB}_{2}\right)$ and prostaglandin $\mathrm{E}_{2}\left(\mathrm{PGE}_{2}\right)$ release by unstimulated and lipopolysaccharide (LPS)-stimulated AMs from wheezy and nonwheezy infants and analysed its regulation by dexamethasone.

\section{Bronchoscopy and bronchoalveolar lavage}

Alveolar macrophages were obtained by bronchoscopy and BAL, as described elsewhere [24]. Briefly, children were premedicated with atropine and midazolam and upper and lower airway anaesthesia was obtained with 2 and $0.5 \%$ lidocaine, respectively. The bronchofibrescope (Olympus BF3C30; Olympus Winter IBE Gmbh, Hamburg, Germany) was wedged into a subsegmental bronchus of the right lower lobes and prewarmed sterile saline $\left(4 \mathrm{~mL} \cdot \mathrm{kg}\right.$ body weight $\left.{ }^{-1}\right)$ was instilled in 10 $\mathrm{mL}$ aliquots and withdrawn by gentle aspiration. The first aliquot was sent for viral detection by immunofluorescence, and the remaining recovered fluid was immediately filtered through two layers of sterile surgical gauze, collected into sterile polypropylene vials (Falcon 50 mL; Becton Dickinson, Rutherford, NJ, USA) and kept on ice until centrifugation.

\section{Isolation and culture of alveolar macrophages}

The lavage fluid was centrifuged at $470 \times \mathrm{g}$ for $10 \mathrm{~min}$ at $4{ }^{\circ} \mathrm{C}$. The cell pellet was resuspended at a cell concentration of $1 \times 10^{6} \cdot \mathrm{mL}^{-1}$ in RPMI 1640 medium (GibcoBRL, Paisley, Scotland) supplemented with $3 \%$ endotoxin-free heat-inactivated foetal calf serum (Boehringer Mannheim, Mannheim, Germany), penicillin (100 U.mL-1), streptomycin $\left(100 \mu \mathrm{g} \cdot \mathrm{mL}^{-1}\right)$ and amphotericin B $(0.25$ $\left.\mu \mathrm{g} \cdot \mathrm{mL}^{-1}\right)$. All antibiotics were purchased from GibcoBRL. An aliquot of the cell suspension was removed to determine cell numbers and differential cell counts. Approximately $1 \times 10^{6}$ viable cells were distributed in sterile $22 \mathrm{~mm} \mathrm{12-well} \mathrm{tissue} \mathrm{culture} \mathrm{plates} \mathrm{(Costar,}$ Cambridge, MA, USA) and AMs were isolated by adhesion to the plates. After $1 \mathrm{~h}$ incubation at $37^{\circ} \mathrm{C}$ in $95 \%$ air $/ 5 \% \mathrm{CO}_{2}$, nonadherent cells were removed by washing twice with warmed culture medium, and AMs were then stimulated for $18 \mathrm{~h}$ in the presence or absence of dexamethasone.

\section{Stimulation of alveolar macrophages}

Escherichia coli endotoxin (LPS: serotype 055: $\mathrm{B}_{5}$; Difco, Detroit, MI, USA) was used as a TNF- $\alpha$ inducer. Different concentrations of LPS were tested (data not shown) and, subsequently, an optimal concentration of $10 \mu \mathrm{g} \cdot \mathrm{mL}^{-1}$ was chosen. The AMs were either left in a resting state or cultured in the presence of LPS for 18 $\mathrm{h}$ at $37^{\circ} \mathrm{C}$. At the end of the incubation period the supernatants from unstimulated and from endotoxin activated cultures were collected, centrifuged and stored at $-70^{\circ} \mathrm{C}$ for later determination of metabolite concentrations. 
In vitro exposure of alveolar macrophages to dexamethasone

The limited number of cells recovered by BAL did not allow us to test the effect of dexamethasone on the stimulated release of proinflammatory mediators by AMs in three of the seven controls. To investigate the effects of in vitro dexamethasone on the LPS-stimulated release of eicosanoids and TNF- $\alpha$ by AMs, adherent AMs from wheezy and control children were exposed to $1 \mu \mathrm{M}$ dexamethasone (dexamethasone 21-phosphate, disodium salt; Sigma, St Louis, MO, USA) 1 min before adding the endotoxin, and allowed to incubate overnight in the presence of both products. At the end of the incubation period, aliquots of cells supernatants were removed and stored at $-70^{\circ} \mathrm{C}$ for quantification of metabolites.

\section{Determination of $T N F-\alpha$}

A two-site sandwich enzyme-linked immunosorbent assay (ELISA) for human TNF- $\alpha$ was developed using a monoclonal capture antibody (mouse Immunoglobulin G (IgG) 1k code M 300 A; Endogen, Boston, MA, USA), a polyclonal $\mathrm{IgG}$ fraction of rabbit antiserum against human recombinant TNF- $\alpha$ (a gift from S. Mamas, Institut Pasteur, Paris, France) and recombinant TNF- $\alpha$ (E. coli-derived, specific activity $5 \times 10^{7} \mathrm{U} \cdot \mathrm{mg}^{-1}$, kindly provided by Bender-Wien, Vienna, Austria). The stock solution of the monoclonal antibody was diluted in phosphate buffered saline (PBS) (phosphate buffer $0.01 \mathrm{M}$, pH 7.4 in $0.14 \mathrm{M} \mathrm{NaCl}$ ), to obtain $5 \mu \mathrm{g} \cdot \mathrm{mL}^{-1}$, and then was allowed to coat 96-well flat-bottom microtitre plates (Nunclon Delta, Roskilde, Denmark), $100 \mu \mathrm{L} \cdot \mathrm{well}^{-1}$, overnight at room temperature. After three washes (PBS Tween $20,0.1 \% \mathrm{v} / \mathrm{v})$ the plates were post-coated with $200 \mu \mathrm{L}$ PBS-bovine serum albumin (BSA) $1 \% \mathrm{w} / \mathrm{v}$, for $1 \mathrm{~h}$, at $37^{\circ} \mathrm{C}$, in order to block unoccupied binding sites on the plastic plate. Following three other washes in PBS-Tween 20, culture supernatants from AMs (100 $\mu \mathrm{L} \cdot$ well $^{-1}$ diluted to $1 / 30,1 / 100$ and $1 / 300$ in PBS-BSA $0.1 \%$ ) or freshly diluted standard concentrations of recombinant TNF- $\alpha$ were incubated in the wells for $1 \mathrm{~h}$ at $37^{\circ} \mathrm{C}$. After three washes, $100 \mu \mathrm{L}$ of the polyclonal rabbit antiserum was added (diluted to $1 / 300$ in PBSBSA $0.1 \%$ ) and the plates were further incubated for 2 $\mathrm{h}$ at $37^{\circ} \mathrm{C}$. The plates were washed again prior to incubation for $1 \mathrm{~h}$ at $37^{\circ} \mathrm{C}$ with $100 \mu \mathrm{L} \cdot \mathrm{well}^{-1}$ of a peroxidase conjugate of goat anti-rabbit IgG (Fab), diluted to $1 / 2,000$ in PBS-BSA 0.1\% (code B1 3407; Biosys, Compiègne, France). Following another wash, $100 \mu \mathrm{L} \cdot$ well $^{-1}$ freshly prepared O-phenylendiamine dihydro-chloride (OPD) (Sigma, St Louis, MO, USA) $2 \mathrm{~g} \cdot \mathrm{L}^{-1}$ in PBS 0.01 $\mathrm{M}$, pH 7.3, containing $0.02 \mathrm{M}$ hydrogen peroxide $\left(\mathrm{H}_{2} \mathrm{O}_{2}\right)$ was added and the plates were incubated in the dark at room temperature for $7 \mathrm{~min}$. Colour development was stopped with $50 \mu \mathrm{L} \cdot$ well ${ }^{-1}$ of sulphuric acid $\left(\mathrm{H}_{2} \mathrm{SO}_{4}\right)$ containing $0.5 \%$ sodium sulphite $\left(\mathrm{Na}_{2} \mathrm{SO}_{3}\right)$. Optical density was measured in an automatic reader with a test wavelength of $490 \mathrm{~nm}$ and a reference wavelength of $630 \mathrm{~nm}$ (MR 5000/7000; Dynatech, Saint Cloud, France). The sample concentrations were derived from linear regression analysis of a log-log standard plot, run on each plate (from 3 to $600 \mathrm{pg} \cdot 100 \mu \mathrm{L}^{-1}$, diluted in $0.1 \%$ PBS-BSA).

\section{Determination of arachidonic acid metabolites}

Arachidonic acid metabolites $\mathrm{PGE}_{2}$ and $\mathrm{TxB}_{2}$ (the stable breakdown product of thromboxane $\mathrm{A}_{2}$ ) were measured by radioimmunoassay as described by Sors et al. [25]. Briefly, $100 \mu \mathrm{L}$ of each sample was incubated overnight at $4^{\circ} \mathrm{C}$ with iodine-125-labelled $\mathrm{TxB}_{2}$ or with iodine-125-labelled $\mathrm{PGE}_{2}$, and anti- $\mathrm{TxB}_{2}$ or anti-PGE antiserum in phosphate buffer $(0.1 \mathrm{M}$ at $\mathrm{pH} 7.4)$ containing $0.3 \% \mathrm{w} / \mathrm{v}$ bovine gamma-globulins (Sigma). The next day, bound and free ligands were separated by addition of a solution of polyethyleneglycol 6000 (Merck, Darmstadt, Germany), $30 \% \mathrm{w} / \mathrm{v}$ in distilled water, followed by centrifugation for $10 \mathrm{~min}$ at $3,000 \times \mathrm{g}$ at $4^{\circ} \mathrm{C}$. The supernatants were decanted and the radioactivity present in the pellet (bound fraction) was counted for 1 min in a gamma counter (model MDA 312; Kontron Analytical, Zurich, Switzerland). The monoclonal antibodies employed were less than $0.02 \%$ crossreactive with $\mathrm{PGD}_{2}, \mathrm{PGE}_{2}, \mathrm{PGF}_{2 \alpha}, 6$-keto-PGF $\mathrm{PG}_{1 \alpha}$, and arachidonic acid, for the anti-TxB ${ }_{2}$ antiserum; and $70 \%$ crossreactive with $\mathrm{PGE}_{1}, 10 \%$ with 6-keto $\mathrm{PGE}_{1}$ and less than $0.1 \%$ with $\mathrm{PGD}_{2}, \mathrm{PGF}_{2 \alpha}, \mathrm{TxB}_{2}$ and arachidonic acid for the anti-PGE 2 antiserum. The sensitivity of the assay is approximately $2 \mathrm{pg}$ and $4 \mathrm{pg}$ of immunoreactive $\mathrm{TxB}_{2}$ and $\mathrm{PGE}_{2}$, respectively, in $100 \mu \mathrm{L}$ samples.

\section{Additional methods}

Total cell counts were evaluated with a haemacytometer (Malassez, Preciss, Strasbourg, France), and cell viability was determined by the trypan blue dye exclusion test. Differential cell counts were obtained by a modified Wright-Giemsa staining (Diff-Quik; Baxter Dade AG, Duedingen, Switzerland) of cytocentrifuged smears from BAL cell suspensions. At least 300 cells were examined for every specimen. For mast cell counts, smears were stained by $1 \%$ alcian blue, after fixation in Carnoy's fluid.

At the end of each experiment the AM monolayers were washed with sterile saline solubilized in $1 \mathrm{~mL}$ of $0.1 \%$ Triton X-100 (Sigma) and scraped off the dishes. Protein content of the cell lysates was determined using the bicinchoninic acid (BCA) protein assay kit (Pierce, Rockford, IL, USA) and BSA as a standard. The conversion factor used for correction of the number of adherent cells was $200 \mu \mathrm{g}$ protein corresponding to $1 \times$ $10^{6}$ cells. Cell viability at the end of the experiments was assessed by lactic dehydrogenase release using a commercial kit (Boehringer, Mannheim, Germany) and by the trypan blue dye exclusion test on cells monolayers, and averaged $80-90 \%$.

\section{Statistical analysis}

Data are expressed as the median, with ranges from 25th to 75th percentiles in parentheses. Comparison of data between groups was performed by the Mann-Whitney two-sample U-test for unpaired data. Comparisons evaluating the effects of endotoxin and dexamethasone on metabolites release by AMs were made using the Wilcoxon's signed rank test. A p-value of less than 0.05 was accepted as significant. 


\section{Results}

\section{Flexible bronchoscopy and bronchoalveolar lavage}

No major complications were observed during bronchoscopy and BAL in both wheezy and control children. The total number of nucleated cells was $0.38 \times 10^{6}$ $\left(0.28 \times 10^{6}-0.41 \times 10^{6}\right)$ cells $\cdot \mathrm{mL} \mathrm{BAL}^{-1}$ in wheezy children and $0.30 \times 10^{6}\left(0.23 \times 10^{6}-0.42 \times 10^{6}\right)$ cells $\cdot \mathrm{mL} \mathrm{BAL}^{-1}$ in control children (NS). The viability of BAL cells was similar in both wheezy and control children (72 (68-79) $\%$ versus 74 (66-77) \%; Ns) and epithelial cells were always nonviable. The percentage of macrophages, neutrophils, lymphocytes and eosinophils did not differ statistically between the groups (table 1), but the wheezy children had an increased percentage of epithelial cells as compared to controls $(p<0.05)$. Eosinophils were identified in only one wheezy infant (who had $0.3 \%$ eosinophils in BAL) and in none of the controls. Mast cell numbers were always below $0.08 \%$, in both groups of children.
$T N F-\alpha$ release

The levels of metabolites released by cultured AMs from wheezy and control children are depicted in table 2. The spontaneous release of TNF- $\alpha$ was significantly higher in wheezy children than in controls $(\mathrm{p}<0.05)$. The release of TNF- $\alpha$ by unstimulated AMs ranged $0.1-11.2$ $\mathrm{ng} \cdot 10^{6}$ cells $^{-1}$ and $0.1-1.6 \mathrm{ng} \cdot 10^{6}$ cells $^{-1}$, in wheezy and control children, respectively (fig. 1). The spontaneous release of TNF- $\alpha$ was $1.52(0.75-6.52) \mathrm{ng} \cdot 10^{6}$ cells $^{-1}$ versus 2.61 (1.31-3.64) ng.106 cells-1 in wheezers with or without an history of atopy-related diseases in the family, respectively (NS).

The release of TNF- $\alpha$ by LPS-exposed AM cultures was significantly increased, as compared to unstimulated preparations $(\mathrm{p}<0.05)$. The mean value of LPS-induced release of TNF- $\alpha$ increased 13 fold (median sixfold) and 78 fold (median 20 fold) over the unstimulated release in wheezy and control children, respectively (Ns). Thus, the capacity for the inducer-related release of TNF- $\alpha$ was lower in the wheezy children but the difference was not statistically significant.
Table 1. - Bronchoalveolar lavage (BAL) cellular profile in wheezy and control infants

\begin{tabular}{lccccc}
\hline & $\begin{array}{c}\text { Total } \\
\text { cells } \cdot \mathrm{mL}^{-1}\end{array}$ & $\begin{array}{c}\text { Epithelial cells } \\
\%\end{array}$ & $\begin{array}{c}\text { Macrophages } \\
\%\end{array}$ & $\begin{array}{c}\text { Lymphocytes } \\
\%\end{array}$ & $\begin{array}{c}\text { Neutrophils } \\
\%\end{array}$ \\
\hline Wheezers & 0.38 & 7.2 & 85.1 & 4.5 & 3.2 \\
$(\mathrm{n}=13)$ & $(0.28-0.41)$ & $(4.3-8.2)^{*}$ & $(74.5-90.0)$ & $(2.9-13.6)$ & $(0.7-4.6)$ \\
Controls & 0.30 & 2.1 & 91.1 & 4.0 & 0.8 \\
$(\mathrm{n}=7)$ & $(0.23-0.42)$ & $(1.8-6.4)$ & $(86.9-95.7)$ & $(2.5-9.2)$ & $(0-1.0)$ \\
\hline
\end{tabular}

Eosinophils were identified in only one wheezy infant (who had $0.3 \%$ eosinophils in BAL) and in none of the controls. Mast cell numbers were always below $0.08 \%$, in both groups of children. Results represent medians, with interquartile ranges in parentheses. *: $\mathrm{p}<0.05$, versus control infants.

Table 2. - Release of tumour necrosis factor- $\alpha$ (TNF- $\alpha$ ) and cyclo-oxygenase metabolites by alveolar macrophages (AMs) from infants

\begin{tabular}{lccc}
\hline & \multicolumn{3}{c}{ Metabolite release } \\
\cline { 2 - 4 } & Unstimulated AMs & LPS-stimulated AMs & $\begin{array}{c}\text { LPS-stimulated AMs } \\
+ \text { dexamethasone } \\
\text { ng } 10^{6} \text { cells }^{-1}\end{array}$ \\
\hline TNF- $\alpha$ & $n g \cdot 10^{6}$ cells $^{-1}$ & $n g \cdot 10^{6}$ cells $^{-1}$ & \\
Wheezers & & & 5.71 \\
Controls & 2.67 & 15.24 & $(4.78-20.85)^{\S}$ \\
& $(0.89-8.33)^{*}$ & $(7.80-25.66)^{\dagger}$ & 6.76 \\
TxB & 0.48 & 22.99 & $(5.58-8.53)^{\S}$ \\
Wheezers & $(0.25-1.08)$ & $(8.18-28.86)^{\dagger}$ & 245.50 \\
Controls & 75.63 & 377.80 & $(54.04-336.76)^{\S}$ \\
& $(38.07-158.91)^{*}$ & $(165.61-458.76)^{\dagger}$ & 50.79 \\
PGE & 10.03 & 206.87 & $(26.58-157.04)^{\S}$ \\
Wheezers & $(7.36-76.08)$ & $(44.88-481.57)^{\dagger}$ & 7.84 \\
Controls & 2.39 & 17.56 & $(2.32-11.14)^{\S}$ \\
& $(0.58-4.50)$ & $(6.40-29.12)^{\dagger}$ & 10.10 \\
\hline Levis & 0.41 & 22.74 & $(7.48-19.55)^{\S}$ \\
\hline
\end{tabular}

Levels of metabolites were measured in supernatants from unstimulated and lipopolysaccharide (LPS)-stimulated AMs from 13 wheezy and 7 control children, in the presence or absence of dexamethasone. Results represent medians, with interquartile ranges in parentheses. $\mathrm{TxB}_{2}$ : thromboxane $\mathrm{B}_{2} ; \mathrm{PGE}_{2}$ : prostaglandin $\mathrm{E}_{2}$. *: $\mathrm{p}<0.05$, versus control infants; $\dagger: \mathrm{p}<0.005$, versus unstimulated AMs; $\S$ : $\mathrm{p}<0.05$, versus LPS-stimulated AMs not treated with dexamethasone.
Immunoreactive eicosanoids release

Under resting conditions, AMs from wheezy children released increased amounts of $\mathrm{TxB}_{2}$ as compared to AMs from controls (fig. 2). The spontaneous release of $\mathrm{TxB}_{2}$ by AMs ranged 12.5$340.1 \mathrm{ng} \cdot 10^{6}$ cells $^{-1}$ and $0.8-125.9$ $\mathrm{ng} \cdot 10^{6}$ cells $^{-1}$ in wheezy and control children, respectively. The release of $\mathrm{PGE}_{2}$ by unstimulated AMs tended to be higher in wheezy than in control children, but the difference observed was below the level of significance. There was also a larger degree of intersubject variability among wheezy infants, than among controls, for the spontaneous release of $\mathrm{PGE}_{2}$ by AMs, ranging $0.2-19.4$ $\mathrm{ng} \cdot 10^{6}$ cells $^{-1}$ and $0.3-2.9 \mathrm{ng} \cdot 10^{6}$ cells $^{-1}$ in wheezy and control children, respectively.

Stimulation with LPS induced a significant increase in the release of $\mathrm{TxB}_{2}$ and $\mathrm{PGE}_{2}$ by $\mathrm{AMs}$ from both populations. A mean value of sixfold (median twofold) and 32 fold (median fivefold) increase in the release of $\mathrm{TxB}_{2}$ by AMs over the unstimulated release were observed in wheezy and control children, respectively. The mean value of LPS-induced release of $\mathrm{PGE}_{2}$ increased 10 fold (median sixfold) and 67 fold (median 16 fold) over the unstimulated release in wheezy and control children, respectively. 


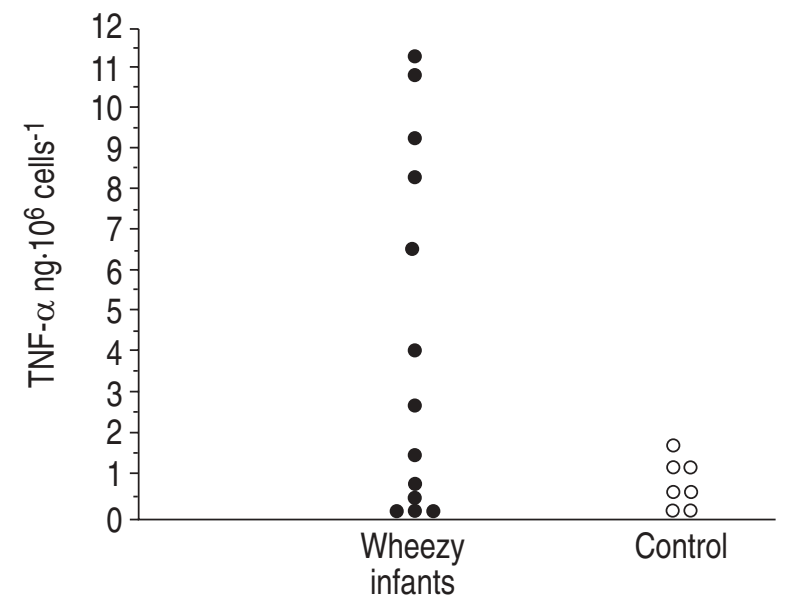

Fig. 1. - Spontaneous release of tumour necrosis factor- $\alpha$ (TNF- $\alpha)$ by alveolar macrophages (AMs) from 13 wheezy $(\bullet)$ and 7 control (O) infants. AMs were incubated for $18 \mathrm{~h}$ in the absence of stimulus. TNF- $\alpha$ release by AMs was greater in wheezy infants $(\mathrm{p}<0.05)$.
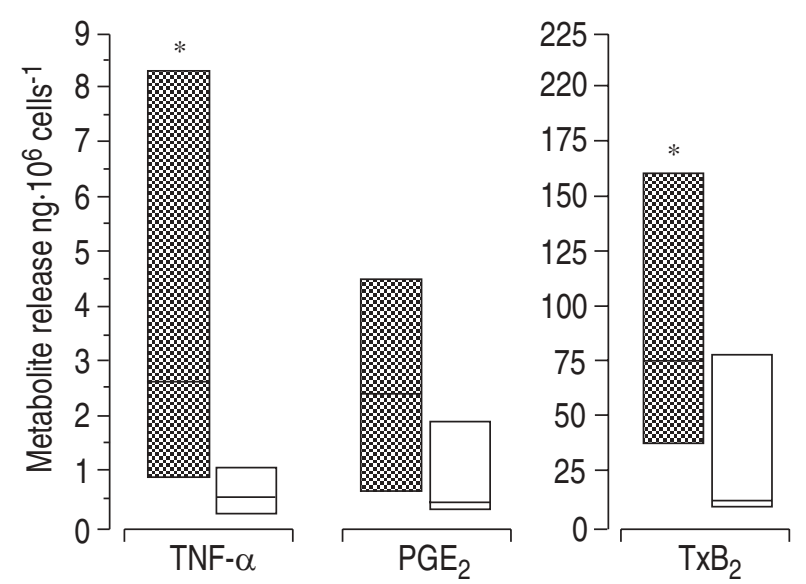

Fig. 2. - Spontaneous release of proinflammatory metabolites by alveolar macrophages (AMs) from 13 wheezy (\%) ) and 7 control ( $\square$ ) infants. AMs were incubated for $18 \mathrm{~h}$ in the absence of stimulus. The horizontal lines of the boxes represent the 25th, 50th and 75 th percentiles of the variables. *: $\mathrm{p}<0.01$, versus control infants. TNF- $\alpha$ : tumour necrosis factor- $\alpha$; $\mathrm{TxB}_{2}$ : thromboxane $\mathrm{B}_{2} ; \mathrm{PGE}_{2}$ : prostaglandin $\mathrm{E}_{2}$.

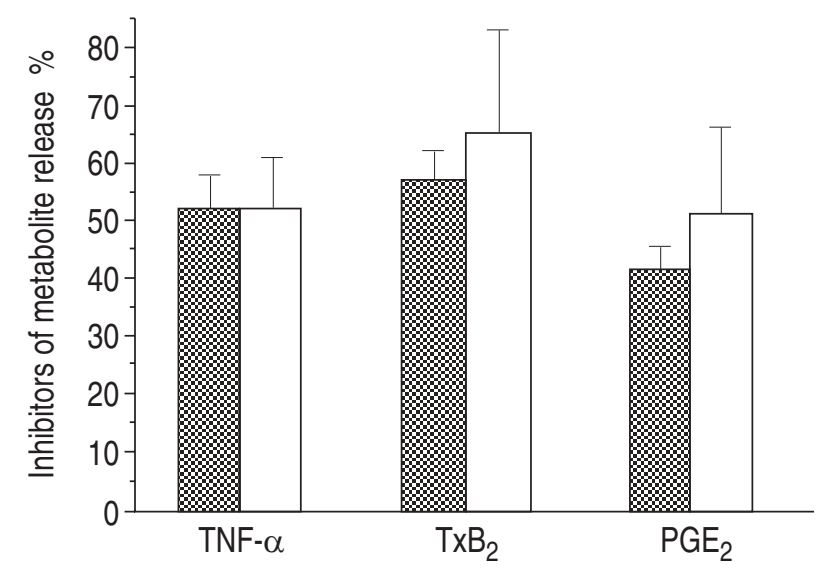

Fig. 3. - Effects of dexamethasone on the release of metabolites by lipopolysaccharide (LPS)-stimulated alveolar macrophages (AMs). AMs from wheezy infants ( $\$$ Q $)$ and control infants ( $\square$ ) were incubated for $18 \mathrm{~h}$ with $10 \mu \mathrm{g} \cdot \mathrm{mL}^{-1}$ LPS and dexamethasone. Dexamethasone indicated a consistent and similar inhibition of the LPS-stimulated release of metabolites in both wheezy and control infants. Values represent mean \pm SEM.
Effects of dexamethasone on TNF- $\alpha$ and eicosanoids release

The effects of dexamethasone on the release of proinflammatory mediators by LPS-stimulated AMs are shown in figure 3. Dexamethasone induced a substantial and uniform inhibition of the LPS-stimulated release of both TNF- $\alpha$ and cyclo-oxygenase products by AMs from wheezy and control children $(\mathrm{p}<0.05)$.

\section{Discussion}

In the present study we demonstrate, for the first time, that AMs from wheezy children were activated to release increased quantities of TNF- $\alpha$, when compared to AMs from nonwheezy children. LPS markedly enhanced TNF$\alpha$ generation in both groups of children; however the increase in TNF- $\alpha$ tended to be more marked in the control group than in the wheezy children. Studies have shown that AMs from adults with asthma spontaneously release increased amounts of TNF- $\alpha$ [18, 19], but are less prone to LPS stimulation than AMs from normal subjects [19]. Thus, our observations, showing an increased spontaneous upregulation of AMs but a decreased reaction to stimuli, are in agreement with these studies. The mechanisms involved in the increased spontaneous release of TNF- $\alpha$ by AMs of wheezy infants were not explored in our study. Theoretically, AMs from wheezy infants may be exposed in vivo to a cytokine profile favouring AM activation [20].

The relationship between in vitro and in vivo findings remains to be established. However, since BAL was performed in a symptom-free period, the data presented support the argument in favour of a chronic AM activation in children with recurrent early episodes of wheezing. Detection of higher levels of TNF- $\alpha$ in BAL fluid from wheezy infants would provide a stronger argument in favour of this hypothesis. However, TNF- $\alpha$ levels were not measured in BAL supernatants because at least a 10 fold concentration would have been required to have a chance to detect TNF- $\alpha$, due to the dilution of the epithelial lining fluid in the volume of saline required to perform the lavage.

The wheezy children had a significant increase of epithelial cell percentage in BAL. This finding, also described in asthmatic adults [20], could be an argument in favour of an increased activation of inflammatory cells in vivo. The exposure of the epithelium to inflammatory mediators, such as cytokines, could result in an increased epithelial shedding into the airways of wheezy children. However, this could also be explained by an increased percentage of bronchial fluid, versus alveolar fluid, in the recovered BAL.

We restricted our population of wheezy children to a subset with frequent moderate-to-severe symptoms, in whom fibreoptic bronchoscopy was clinically indicated to search for underlying causes of wheezing [26]. Therefore, our results do not necessarily apply to the entire population of wheezy infants since, according to epidemiological surveys [1], we probably selected a subset of wheezers with an increased predisposition to asthma.

Our decision to use as controls children with other types of lung disease, in whom fibreoptic bronchoscopy 
was justified for diagnostic purposes, makes the interpretation of data difficult, as the differences observed could be due to an altered release of mediators in the control children, instead of an increased release in the wheezy infants. In order to minimize this error of interpretation, we chose as controls children with a variety of pathologies including pulmonary tuberculosis, since Mycobacterium tuberculosis and its components are known to enhance TNF- $\alpha$ expression and secretion by human monocytes and macrophages, in vivo and in vitro [27-29]. An increased secretion of interleukin (IL)-10 by $M$. tuberculosis-infected macrophages, which was not measured in this study but has already been demonstrated in infected adults [30], could have inhibited the release of TNF- $\alpha$ by AMs from children with tuberculosis [31]. However, investigators agree that there is increased TNF- $\alpha$ production by macrophages in tuberculous patients (e.g. [27]), independent of the other cytokines produced. Furthermore, TNF- $\alpha$ is thought to be responsible for much of the granuloma formation associated with the disease, and children with tuberculosis often exhibit endobronchial granulomatous lesions [32]. Therefore, the higher spontaneous release of TNF- $\alpha$ observed in AMs from wheezy infants is likely to derive from activation of cells from wheezy infants rather than from deactivation of controls cells.

The age of the controls was slightly but significantly higher than the age of the wheezy infants. If TNF- $\alpha$ production was related to a different degree of maturation of the immune system, it could have accounted for a decreased TNF- $\alpha$ production in controls as compared to wheezers. However, age alone is unlikely to have accounted for the differences observed, as the release of TNF- $\alpha$ did not correlate with the age of the children, and AMs from control adults released similar levels of TNF- $\alpha$ (data not shown).

Macrophages are also a source of eicosanoids, mediators that may be implicated in asthma pathogenesis. In a previous study [6], we demonstrated that AMs taken from wheezy infants and incubated for a short period, had an increased spontaneous release of bronchoconstrictor $\mathrm{TxB}_{2}$. In the present study, conducted under different experimental conditions, we corroborated our previous findings. When incubated overnight, resting AMs from wheezy infants released increased amounts of $\mathrm{TxB}_{2}$ as compared to AMs from controls.

In asthmatic adults, glucocorticoids inhibit the activation of several inflammatory cells implicated in the disease [33]. The inhibition of TNF- $\alpha$ release by AMs is one of the mechanisms evoked for their anti-inflammatory action [34]. In our study, LPS-stimulated TNF- $\alpha$ release by AMs was extremely sensitive to inhibition by dexamethasone in both groups of children. In accordance with our previous findings [6], dexamethasone also induced a consistent inhibition of the release of cyclo-oxygenase metabolites by LPS-stimulated AMs. This point can be relevant to the clinical care of children, as it is theoretically possible that an early therapeutic intervention with anti-inflammatory drugs might prevent the deterioration of lung function observed with ageing [1].

TNF- $\alpha$ is an important proinflammatory cytokine and could provide a local mechanism to potentiate inflammation at the airway level in wheezy children. However, the kinetics and final balance, in vivo, between the production of TNF- $\alpha$ and of other potentially agonist and antagonist factors, such as the recently described soluble receptor factors for TNF- $\alpha$, sTNF-RI and sTNFRII, and other proinflammatory or inhibitory cytokines, are far from being completely understood [35]. Further research is required to determine whether a chronic inflammation of the airways is indeed present in wheezy infants, and can be ameliorated by in vivo treatment with glucocorticoids.

In conclusion, we have demonstrated that alveolar macrophages from infants with recurrent episodes of wheezing, spontaneously generate increased amounts of tumour necrosis factor- $\alpha$ and thromboxane $B_{2}$ when compared to controls. Our data suggest the presence of an ongoing activation of alveolar macrophages in the airways of wheezy infants, even during asymptomatic periods. In addition, dexamethasone was a consistent in vitro inhibitor of the release of proinflammatory mediators by alveolar macrophages, supporting the hypothesis that infants with recurrent wheezing episodes may eventually benefit from treatment with glucocorticoids.

\section{References}

1. Martinez FD, Wright AL, Taussig LM, Holberg CJ, Halonen M, Morgan WJ, and the Group Health Medical Associates (GHMA). Asthma and wheezing in the first six years of life. N Engl J Med 1995; 332: 133-138.

2. Laitinen LA, Laitinen A, Haahtela T. Airway mucosal inflammation even in patients with newly diagnosed asthma. Am Rev Respir Dis 1993; 147: 697-704.

3. Bousquet J, Chanez P, Campbell AM, Vignola AM, Godard P. Cellular inflammation in asthma. Clin Exp Allergy 1995; 25: S39-S42.

4. Chanez P. Bousquet J, Couret I, et al. Increased numbers of hypodense alveolar macrophages in patients with bronchial asthma. Am Rev Respir Dis 1991; 144: 923-930.

5. Damon M, Chavis C, de Paulet AC, Michel FB, Godard P. Arachidonic acid metabolism in alveolar macrophages: a comparison of cells from healthy subjects, allergic asthmatics, and chronic bronchitis patients. Prostaglandins 1987; 34: 291-309.

6. Azevedo I, de Blic J, Scheinmann P, Vargaftig BB, Bachelet M. Enhanced arachidonic acid metabolism in alveolar macrophages from wheezy infants: modulation by dexamethasone. Am J Respir Crit Care Med 1995; 152: 1208-1214.

7. Bachwich PR, Lynch JP III, Larrick J, Spengler M, Kunkel SL. Tumor necrosis factor production by human sarcoid alveolar macrophages. Am J Pathol 1986; 125: 421-425.

8. Lassalle P, Gosset P, Delneste Y, et al. Modulation of adhesion molecule expression on endothelial cells during the late asthmatic reaction: role of macrophagederived tumor necrosis factor-alpha. Clin Exp Immunol 1993; 94: 105-110.

9. Ming WJ, Bersani L, Mantovani A. Tumor necrosis factor is chemotactic for monocytes and polymorphonuclear leukocytes. J Immunol 1987; 138: 1468-1474.

10. Benyon RC, Bissonette EY, Befus AD. Tumor necrosis factor alpha-dependent cytotoxicity of human skin mast cells is enhanced by anti-IgE antibodies. J Immunol 1991; 147: 2253-2258.

11. Silberstein DS, Davis JR. Tumor necrosis factor/cachectin 
stimulates eosinophil toxicity to Shistosoma mansoni larvae. Proc Natl Acad Sci USA 1986; 83: 1053-1059.

12. Vilcek J, Palombella VJ, Henriksen-DeStefano D, et al. Fibroblast growth enhancing activity of tumor necrosis factor and its relationship to other polypeptide growth factors. J Exp Med 1986; 163: 632-643.

13. Thomas PS, Yates DH, Barnes PJ. Tumor necrosis factor- $\alpha$ increases airway responsiveness and sputum neutrophilia in normal human subjects. Am J Respir Crit Care Med 1996; 152: 76-80.

14. Broide DH, Lotz M, Cuomo AJ, Coburn DA, Federman EC, Wasserman SI. Cytokines in symptomatic asthma airways. J Allergy Clin Immunol 1992; 89: 958-967.

15. Virchow J-C Jr, Walker C, Hafner D, et al. T-cells and cytokines in bronchoalveolar lavage fluid after segmental allergen provocation in atopic asthma. Am J Respir Crit Care Med 1995; 151: 960-968.

16. Ying S, Robinson DS, Varney V, et al. TNF- $\alpha$ mRNA expression in allergic inflammation. Clin Exp Allergy 1991; 21: 745-750.

17. Cembrzynska-Nowak M, Szklarz E, Inglot AD, TeodorczykInjeyan JA. Elevated release of tumor necrosis factoralpha and interpheron-gamma by bronchoalveolar 1 eukocytes from patients with bronchial asthma. Am Rev Respir Dis 1993; 147: 291-295.

18. Gosset P, Tsicopoulos A, Wallaert B, Joseph M, Capron $\mathrm{A}$, Tonnel AB. Tumor necrosis factor alpha and interleukin-6 production by human mononuclear phagocytes from allergic asthmatics after IgE-dependent stimulation. Am Rev Respir Dis 1992; 146: 768-774.

19. Chanez $\mathrm{P}$, Vignola AM, Paul-Eugène $\mathrm{N}$, et al. Modulation by interleukin-4 of cytokine release from mononuclear phagocytes in asthma. J Allergy Clin Immunol 1994; 94: 997-1005.

20. Gosset P, Tsicopoulos A, Wallaert B, et al. Increased secretion of tumor necrosis factor- $\alpha$ and interleukin- 6 by alveolar macrophages consecutive to the development of the late asthmatic reaction. J Allergy Clin Immunol 1991; 88: 561-571.

21. Balfour-Lynn IM, Valman HB, Wellings R, Webster ADB, Taylor GW, Silverman M. Tumor necrosis factor- $\alpha$ and leukotriene $\mathrm{E}_{4}$ production in wheezy infants. Clin Exp Allergy 1994; 24: 121-126.

22. Bisgard H, Munck S, Nielsen J, Petersen W, Ohlsson $\mathrm{S}$. Inhaled budesonide for treatment of recurrent wheezing in early childhood. Lancet 1990; 336: 649-651.

23. de Blic J, Delacourt C, le Bourgeois M, et al. Efficacy of nebulized budesonide in treatment of severe infantile asthma: a double blind study. J Allergy Clin Immunol 1996; 98: 14-20.
24. Galoppin L, de Blic J, Azevedo I, Scheinmann P, Vargaftig $\mathrm{BB}$, Bachelet M. Nonspecific refractoriness to adenyl cyclase stimulation in alveolar macrophages from infants with recurrent bronchiolitis. J Allergy Clin Immunol 1994; 93: 885-890.

25. Sors H, Pradelles P, Dray F. Analytical methods for $\mathrm{TxB}_{2}$ measurement and validation of radioimmunoassay by gas liquid chromatography-mass spectrometry. Prostaglandins 1978; 16: 277-290.

26. de Blic J, Scheinmann P. Fibreoptic bronchoscopy in infants. Arch Dis Child 1992; 67: 159-161.

27. Law K, Weiden M, Harkin T, Tchou-wong K, Chi C, Rom WN. Increased release of interleukin-1 beta, interleukin-6 and tumor necrosis factor-alpha by bronchoalveolar cells lavaged from involved sites in pulmonary tuberculosis. Am J Respir Crit Care Med 1996; 153: 799-804.

28. Barnes PF, Fong S, Brennan PJ, Twomey PE, Mazunder A, Modlin RL. Local production of tumor necrosis factor and IFN-gamma in tuberculous pleuritis. J Immunol 1990; 145: 149-154.

29. Cadranel J, Philippe C, Perez J, et al. In vitro production of tumor necrosis factor and prostaglandin $\mathrm{E}_{2}$ by peripheral blood mononuclear cells from tuberculosis patients. Clin Exp Immunol 1990; 81: 319-324.

30. Lin Y, Zhang M, Hofman FM, Gong J, Barnes PF. Absence of a prominent Th2 cytokine response in human tuberculosis. Infect Immun 1996; 64: 1351-1356.

31. Armstrong L, Jordan N, Millar A. Interleukin 10 (IL-10) regulation of tumour necrosis factor-alpha (TNF-alpha) from human alveolar macrophages and peripheral blood monocytes. Thorax 1996; 51: 143-149.

32. de Blic J, Azevedo I, Burren CP, le Bourgeois M, Lallemand D, Scheinmann P. The value of fiberoptic bronchoscopy in childhood pulmonary tuberculosis. Chest 1991; 100: 688-692.

33. Schwiebert LA, Beck LA, Stellato C, Bickel CA, Bochner BS, Schleimer RP. Glucocorticosteroid inhibition of cytokine production: relevance to antiallergic actions. $J$ Allergy Clin Immunol 1996; 97: 143-152.

34. Martinet N, Vaillant P, Charles T, Lambert J, Martinet Y. Dexamethasone modulation of tumor necrosis factor-alpha (cachectin) release by activated normal human alveolar macrophages. Eur Respir J 1992; 5: 67-72.

35. Galve-de Rochemonteix B, Nicod LP, Dayer J. Tumor necrosis factor soluble receptor 75: the principal receptor form released by human alveolar macrophages and monocytes in the presence of interferon gamma. Am J Respir Cell Mol Biol 1996; 14: 279-287. 